\title{
Aplikasi Pengolahan Citra dan Jaringan Syaraf Tiruan Untuk Pengenalan Pola Tulisan Tangan
}

\author{
Endarko* dan Adhitya Aris Wardhana \\ Laboratorium Elektronika dan Instrumentasi, Jurusan Fisika, FMIPA, \\ Institut Teknologi Sepuluh Nopember, Kampus ITS Sukolilo, Surabaya 60111
}

\section{Intisari}

Telah dirancang perangkat lunak untuk pengenalan pola tulisan tangan dengan jaringan syaraf tiruan (JST) yang dikembangkan sebagai generalisasi model matematika dari pembelajaran manusia. Dalam penelitiani ini, dirancang dan dibuat aplikasi perangkat lunak jaringan syaraf tiruan menggunakan metode Backpropagation dengan fungsi aktifasi sigmoid. Pola berupa abjad tulisan tangan dipindai untuk kemudian diidentifikasi menggunakan metode vertical run dan horizontal run encoding untuk mengetahui batas paling kiri, paling kanan, paling bawah dan paling atas dari setiap abjad. Dari 485 data target yang digunakan menghasilkan Sum Square Error (SSE) sebesar 0,0203 dengan nilai output rata-rata sebesar 0,9429 yang mendekati 1 (satu).

KATA KUNCI: Backpropagation, vertical run, horizontal run encoding

\section{PENDAHULUAN}

Perkembangan teknologi khususnya teknologi komputer begitu pesat mengiringi pesatnya perkembangan jaman di saat ini. Disamping pengembangan manusia dalam meningkatkan performa dan kemampuan komputer dari segi hardware (perangkat keras), manusia juga melakukan pengembangan dari segi software (perangkat lunak). Pengembangan piranti lunak tersebut bisa kita lihat mulai dari operating system, software aplikasi, pemrograman dan sampai yang ada di saat sekarang adalah software yang meniru kecerdasan manusia (Artificial Intelligence). Jaringan syaraf tiruan dikatakan kecerdasan buatan karena proses untuk memperoleh pengetahuannya dilakukannya dengan belajar, belajar seperti layaknya manusia [1].

Tujuan penelitian ini adalah, membuat suatu perangkat lunak berbasis kecerdasan buatan untuk mengenali pola (Pattern Recognition) yang diaplikasikan dalam membaca atau mengidentifikasi tulisan manusia untuk kemudian diterjemahkan sebagai tulisan komputer menggunakan metode pembelajaran backpropagation dengan fungsi aktifasi sigmoid [2].

Pada paper ini pembatasan kemampuan software dalam mengenali input antara lain: data input bukan merupakan tulisan latin (ada jeda antara abjad), data input bukan merupakan persamaan matematika, fisika atau yang sejenis, data input adalah tulisan yang berwarna hitam dengan kertas latar belakang berwarna putih, data input tidak mengandung tulisan dengan model hiasan (seperti tulisan terbalik dan lain-lain), dan ada jeda antar abjad, tidak ada over laping antara abjad satu dengan abjad lain disebelahya.

\footnotetext{
*E-MAIL: endarko@physics.its.ac.id endarko@yahoo.com
}

\section{TEORI DASAR}

Jaringan Saraf Tiruan (JST), atau Artificial Neural Networks (ANN) merupakan sistem pemrosesan informasi yang memiliki karakteristik performa tertentu yang didasari atas kinerja sistem saraf biologis. Karakteristik utama dari ANN adalah kemampuannya untuk belajar dari pengalaman. ANN dapat dilatih untuk melakukan fungsi kompleks dalam berbagai aplikasi seperti pengenalan pola, identifikasi, klasifikasi, pengenalan suara dan visi, serta sistem kontrol. ANN dapat dilatih untuk memecahkan masalah yang sulit dilakukan oleh komputer konvensional atau bahkan oleh manusia [3].

Suatu ANN terdiri atas sejumlah besar elemen pemrosesan sederhana yang disebut neuron. Setiap neuron dihubungkan dengan neuron yang lain, dimana penghubungnya memiliki pembobot tertentu. Setiap neuron memiliki fungsi aktivasi (biasanya nonlinier) dari nilai-nilai input yang masuk, yang digunakan untuk menentukan nilai output [4].

\section{A. Backpropagation}

Backpropagation merupakan multi layer Feed Forward (memberikan sinyal kepada neuron atau lapisan selanjutnya) dengan fungsi transfer yang berbeda pada neuron buatan dan merupakan aturan pembelajaran yang powerfull. Backpropagation merupakan jenis teknik descent gradien dengan propagasi gradien error mundur.

Nama backpropagation diperoleh dari fakta bahwa error gradien dari unit tersembunyi diperoleh dari kesalahan penyebaran mundur yang berhubungan dengan unit masukan karena nilai target dari hidden layer tidak diberikan. Pada backpropagation network, fungsi pengaktifan adalah fungsi sigmoid yang mengkompres nilai keluaran masuk kedalam range antara 0 dan 1. Metode backpropagation merupakan salah satu metode pelatihan (training) yang paling banyak digunakan dalam arsitektur ANN Feed Forward. Metode ini juga disebut 
generalized delta rule, karena menggunakan metode gradient descent untuk meminimalkan Sum of Square Error (SSE) dari output jaringan [5].

Metode pelatihan backpropagation terdiri dari tiga tahap : pertama adalah feedforward dari pola pelatihan input, kedua perhitungan backpropagation dari error yang bersesuaian, serta ketiga pengaturan pembobot.

Selama feedforward, setiap unit input (Xi) menerima sinyal input dan meneruskan sinyal ke unit hidden Z1, , Zp. Setiap unit hidden kemudian menghitung aktivasinya dan mengirimkan sinyal (zj) ke setiap unit output. Setiap unit output (Yk) menghitung aktivasinya (yk) untuk menghasilkan respon dari jaringan untuk menentukan pola input.

Selama training, setiap unit output membandingkan aktivasi yang dihitung (yk) dengan nilai targetnya (tk) untuk menentukan error yang bersesuaian pada unit tersebut. Dari error yang didapat, faktor $\mathrm{k}(\mathrm{k}=1,, \mathrm{~m})$ dihitung. $\mathrm{k}$ digunakan untuk mendistribusikan error pada unit output Yk kembali ke unit pada layer sebelumnya (unit hidden yang terhubung pada $\mathrm{Yk}$ ). Hasil tersebut juga digunakan (nantinya) untuk mengupdate pembobot antara layer output dan layer hidden. Dengan cara yang sama, faktor $\mathrm{j}(\mathrm{j}=1,, \mathrm{p})$ dihitung untuk setiap unit hidden $\mathrm{Zj}$. Propagasi balik error ke layer input tidak diperlukan, namun k digunakan untuk meng-update nilai pembobot antara layer hidden dan layer input.

Setelah seluruh faktor dihitung, pembobot untuk seluruh layer disesuaikan secara simultan. Penyesuaian pembobot wjk (dari unit hidden $\mathrm{Zj}$ ke unit output $\mathrm{Yk}$ ) didasarkan pada faktor $\mathrm{k}$ dan aktivasi zj dari unit hidden $\mathrm{Zj}$. Penyesuaian untuk pembobot vij (dari unit input $\mathrm{Xj}$ ke unit hidden $\mathrm{Zj}$ ) didasari atas faktor $\mathrm{j}$ dan aktivasi xi pada unit input $[5,6]$.

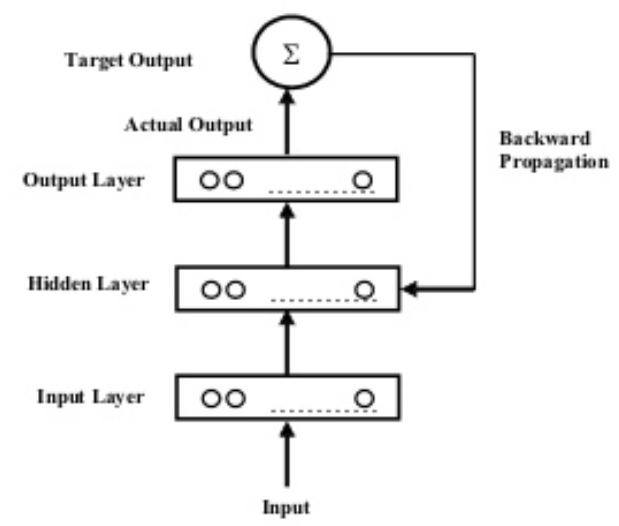

Gambar 1: Arsitektur Jaringan Backpropagation

Fungsi aktifasi sigmoid digambarkan sebagai berikut :

$$
f(x)=\frac{1}{1+\exp (-x)}
$$

dengan

$$
f^{6}(x)=f_{1}(x)\left[1-f_{1}(x)\right]
$$

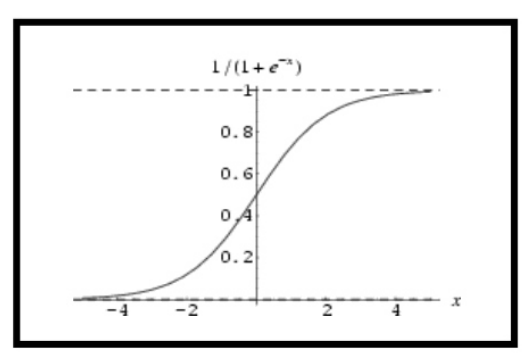

Gambar 2: Fungsi Aktifasi Sigmoid

\section{B. Citra Digital}

Citra digital juga merupakan presentasi dua dimensi yang merupakan bentuk representasi dari tiga dimensi. Pengolahan citra (image processing) merupakan proses yang berhubungan dengan cara untuk peningkatan kualitas suatu citra sehingga menciptakan representasi kepada manusia sesuai dengan yang diinginkan. Sedangkan pencitraan yang dilakukan dalam hal ini adalah machine vision merupakan bentuk representasi komputer dari suatu bentuk ke bentuk bahasa mesin sehingga dapat dimengerti oleh computer [7].

Citra digital dapat dipresentasikan dalam bentuk larik (array) dua dimensi. Array dua dimensi tersebut dapat dinyatakan sebagai matrik. Besar ordo dari matrik yang digunakan tergantung pada tingkat kesesuaian perepresentasian titik-titik atau goresan pada citra digital. Semakin banyak ordo matrik yang digunakan, maka semakin detail pula representasi citra digital. Sebaliknya, semakin sedikit orde dalam matrik, maka tingkat kedetailan citra semakin berkurang.

Setiap posisi pixel dalam matrik merepresentasikan tiap pixel goresan tulisan tangan dalam kertas yang telah di scan.

\section{METODOLOGI PENELITIAN}

Blok diagram perangkat keras terdiri dari obyek berupa tulisan tangan, sebagai obyek tulisan yang akan dikenali, scanner, sebagai media masukan untuk memberikan data ke komputer dan PC (Personal Computer), sebagai perubah sinyal analog menjadi digital dan sebagai pengolah program JST.

Bahasa pemrogramman yang digunakan adalah bahasa pemrogramman visual Borland Delphi 5.0, yang terdiri dari 3 bagian utama yaitu: preprocessing, ekstraksi, dan pembuatan sub-routine untuk jaringan syaraf tiruan (JST).

Pada tahap preprocessing telah dilakukan penyederhanakan gambar. Teknik yang biasa dilakukan dalam pengolahan citra 
adalah dengan melakukan pendeteksian tepian obyek yang berada dalam gambar (Edge Detection). Tulisan dianalisa satu persatu, dipisahkan antar satu abjad dengan abjad yang lain. Pemisahan tiap karakter dengan menggunakan vertical run dan horisontal run encoding, dengan mendeteksi batas paling kiri, paling kanan, paling bawah dan paling atas dari karakter, sambil melihat apakah terjadi perubahan warna mendadak yang melebihi suatu warna antara dua titik yang berimpitan. Jika terjadi perubahan warna yang mendadak, maka di tempat antara kedua titik tersebut dianggap sebagai batas pinggir dari obyek.

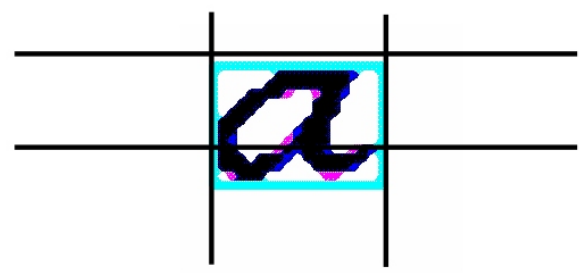

Gambar 3: Pemisahan Karakter.

Garis-garis biru pada tepi karakter merupakan garis hasil pendeteksian tepian. Garis-garis hitam hanya untuk memperjelas pemisahan oleh garis biru. Setiap abjad yang sudah dipisahkan, besar dan ukurannya di konversi kedalam bentuk ukuran matrik ordo 15. Jika tulisan yang di input beukuran lebih kecil dari ordo matrik, maka program menyesuaikan ukurannya menjadi sama besar dengan ordo matrik. Begitu pula jika ukuran input lebih besar dari ordo matrik, program akan menyesuaikan ukurannya menjadi sama besar dengan ordo matrik.

Setelah obyek-obyek berhasil disederhanakan, tahap selanjutnya adalah mengekstraksi ciri-ciri tertentu dari setiap obyek. Abjad yang telah disesuaikan ukurannya dalam proses preprocessing, kemudian dimatrikkan. Scanning pixel dilakukan pada setiap titik, bila ditemukan pixel yang mengalami perubahan mendadak, maka diberi nilai sesuai dengan klasifikasi warnanya (0 dan 1$)$.

Tiap abjad yang telah dimatrikkan tersebut kemudian dimasukkan kedalam Network. Untuk proses pertama adalah proses pembelajaran (training). Pada proses ini, input data yang pertama kali dimasukkan adalah untuk tujuan training, terlihat pada gambar 4.

Metode pembelajaran dalam proses Pemrogramman Jaringan Syaraf Tiruan (JST) menggunakan metode Backpropagation. Struktur Backpropagation yang digunakan dalam aplikasi ini menggunakan 3 lapisan, yaitu lapisan input sebanyak 225 neuron, lapisan hidden (tersembunyi) sebanyak 250 neuron. Sedangkan untuk lapisan output menggunakan 26 neuron.

Proses training dilakukan dengan memasukkan data obyek terekstraksi. Sebelum menjalankan training pada Network, penentuan nilai pembobot ditentukan untuk menentukan perubahan bobot persambungan antara neuron. Pada saat training berjalan, dapat dilihat adanya perbedaan nilai antara target dengan output. Perbedaan nilai antara target dengan output itu

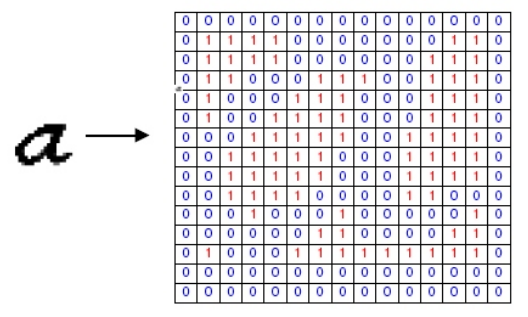

Gambar 4: Contoh pematrikan data input oleh perangkat lunak.

merupakan error, dengan menggunakan sum square error, error tersebut dapat diminimisasi. Diagram alir perangkat lunak dapat dilihat pada gambar 5 .

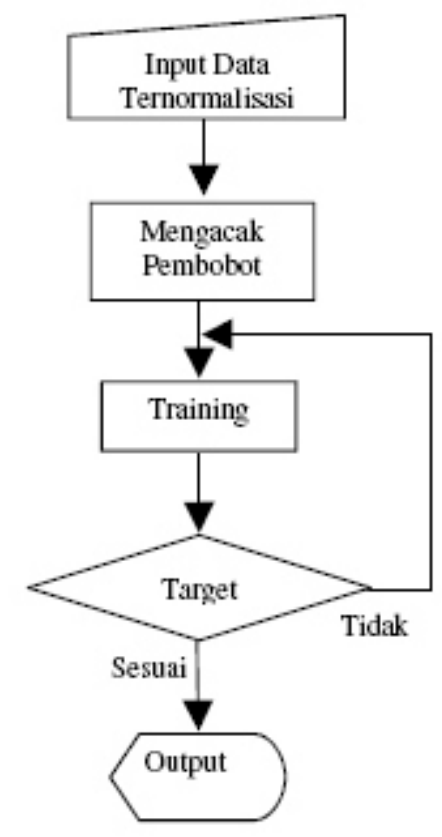

Gambar 5: Diagram Alir Proses Pembelajaran dengan Jaringan Syaraf Tiruan.

\section{ANALISA DAN PEMBAHASAN}

Proses normalisasi data dilakukan dalam beberapa tahap. Tahap pertama adalah pengambilan file gambar dalam format bitmap yang telah disimpan dalam komputer. File tersebut dianalisa perkarakternya, dipisahkan menurut abjadnya.

Pemrograman JST dimulai dengan pembacaan file-file ekstensi '.trn'. Masing-masing suatu koordinat dalam ma- 
trik merupakan presentasi dari setiap layer dari input. Pada proses training, network diperkenalkan dengan data-data input sekaligus dengan target. Sum square error digunakan untuk mengetahui kesalahan antara target yang diminta dengan output. Error yang ditampilkan adalah kuadrat dari target dikurangi dengan output. Proses pembelajaran jaringan tidak berhenti sampai disitu, jika pada pembelajaran antara target dengan output tidak sesuai (ada selisih perbedaan disebut sebagai error), maka disinilah backpropagation bekerja untuk membawa error kembali (loop) kedalam training sampai diperoleh SSE sebesar 0,02.

Pendeteksian tulisan dilakukan dengan identifikasi derajat keabuan 8 bit (28) atau lebih dikenal dengan 256 color, pendeteksian tiap abjad juga dilakukan dengan menggunakan metode vertical run dan horizontal run encoding untuk diketahui batas paling kiri, paling kanan, paling bawah dan paling atas. Warna hitam di encoding kan sebagai 0 (warna dengan tingkat keabuan paling gelap) dan warna putih di encoding kan dengan 1 (warna dengan tingkat keabuan paling terang). Banyak neuron dalam layer input adalah 225 neuron atau orde 15 dalam pematrikan. Pemilihan matrik orde 15 dikarenakan, matrik tersebut dapat memberikan tingkat kerincian yang lebih halus untuk merepresentasikan input. Hidden layer sebanyak 100 neuron. Pada penulisan Penelitian ini digunakan 506 data karakter sebagai input, sehingga dengan banyaknya variabel data seperti itu, akan banyak memakan proses training untuk memperoleh output. Semakin banyak layer hidden, maka semakin teliti dalam mencapai output namun semakin lama dalam memperolehnya dan sebaliknya. Semakin sedikit neuron dalam hidden layer, maka keseksamaan dalam memperoleh output berkurang namun dengan waktu yang lebih cepat. Untuk output layer, digunakan 26 layer sesuai dengan jumlah karakter abjad A sampai dengan $\mathrm{Z}$.

Setelah jaringan dilatih, adanya sedikit perbedaan input dengan target pada penulisan karakter bukanlah suatu masalah bagi jaringan. Jaringan yang sudah memiliki target akan dapat mengidentifikasi sedikit perbedaan detail yang terdapat dalam pola suatu karakter.

Pemanfaatan perangkat lunak untuk mengenali pola (Pattern Recognition) dapat lebih dikembangkan lebih dari sebatas mengenali karakter menjadi untuk mengenali subyek si penulis. Hal ini hampir serupa dengan pengenalan tanda tangan yang langsung dapat mengenali subyek dari penulis. Sehingga dengan kata lain, selain dapat membaca atau mengenali tulisan manusia, program tersebut juga dapat mengidentifikasi subyek penulis dari tulisan yang dituliskannya. Pada dasarnya, penulisan Penelitian ini merupakan salah satu dasar pengenalan pola yang dilakukan oleh Jaringan Syaraf Tiruan. Untuk pengenalan pola dengan menggunakan aplikasi yang lain seperti, pengenalan tanda tangan, sidik jari, suara, wajah dan lain-lain dapat menggunakan dasar dan metode yang sama dengan yang digunakan dalam penulisan ini.

\section{KESIMPULAN}

Perangkat lunak yang telah dihasilkan selain dapat mengidentifikasi karakter abjad juga dapat digunakan untuk menyederhanakan (ekstrak) file gambar dengan metode edge detection. Target yang diberikan dibandingkan dengan keluaran yang dihasilkan mengalami perbedaan.

Data masukan untuk target training berjumlah 485 buah, berkarakter a sampai z dan A sampai Z, abjad kapital dan non kapital dengan range step sebanyak 5200 kali menghasilkan error SSE adalah sebesar 0,0203 dengan nilai keluaran ratarata yang diperoleh adalah 0,9429 (mendekati nilai 1).

Pembuatan perangkat lunak ini menggunakan lapisan masukan sebanyak 225 neuron, lapisan tersembunyi sebanyak 100 neuron dan lapisan keluaran sebanyak 26 neuron.
[1] Rahardjo, Budi.,(2000) Pengenalan Pola Berbasis Neural Network EL - 424, Jurusan Teknik Elektro ITB. Bandung.

[2] Fu, LiMin., (1994), Neural Networks in Computer Intelligence. McGraw-Hill. Inc. New York.

[3] Smith, Prof. Leslie.,(2003),An Introduction to Neural Networks, http://www.cs.stir.ac.uk/ lss/ NNIntro/InvSlides.htm. April 2.

[4] Fraser, Neil., (1998),The Biological Neuron, http://vv.carleton.ca/ neil/neural/ TheBiological Neuron.htm.
September 21.

[5] Rao, Hayagriva, V and Rao, Valuru, B.,(1993), C++ Neural Network and Fuzzy Logic, MIS:Press. New York.

[6] Haykin, Simon., (1994), Neural networks A Comprehensive Foundation, Prentice-Hall. Upper Saddle River. NJ.

[7] Achmad, B., Firdausy, K., (2004), Teknik Pengolahan Citra Digital Menggunakan Delphi, Penerbit Ardi Publishing, Yogyakarta. 